石油技術協会誌 第 59 巻 第 1 号 (平成 6 年 1 月)

JOURNAL OF THE JAPANESE ASSOCIATION FOR PETROLEUM TECHNOLOGY

VOL. 59, NO. 1 (Jan., 1994)

論文・報告

琉球列島伊良部帠の第四系石灰岩の堆積相亡海水準変化*

\author{
本田 信幸 ${ }^{* *}$ ・过 喜弘 ${ }^{* * *}$ ・松田 博貴 ${ }^{* * *}$ ・五月女順一 ${ }^{* * * *}$
}

(Received October 3, 1993; accepted November 24, 1993)

\title{
Sea level changes and development of the Pleistocene Ryukyu Group in the Irabu Island region, southwest Japan.
}

\author{
Nobuyuki Honda, Yoshihiro Tsuji, Hiroki Matsuda \\ and Jun-ichi Saotome
}

\begin{abstract}
Thirteen boreholes were drilled on and around Irabu Island in the southern Ryukyus, from which limestones of the Pleistocene Ryukyu Group $(50 \sim 110 \mathrm{~m})$ were recovered. The seven lithologies in the Group fall into the coral limestone facies and the rhodolith limestone facies. The former is composed mainly of coral floatstone/framestone and the latter is characterized by rhodolith-large foraminifera floatstone/rudstone. By comparing the bio-sedimentary facies of the core samples with those of present sediments around Irabu Is., the coral limestone facies typically represents a reefal-shelf area of $0 \sim 60 \mathrm{~m}$ water depth, and the rhodolith limestone facies an open shelf of $60 \sim 150 \mathrm{~m}$ deep.

The Ryukyu Group is widely distributed on Irabu Is., gently dipping west. It can be divided into three Members, and each separated from its neighbours by a solution unconformity. The Lower Member comprises coral framestone/floatstone and overlies the Shimajiri Group with an angular unconformity, which gradually dips westward. The Middle Member is characterized by five cyclic sequences of alternating coral limestone facies (Unit C-1, C-2, C-3, C-4, C-5) and rhodolith limestone facies (Unit R-1, R-2, R-3, R-4). However, the coral limestone facies dominates in the eastern hilly area but abruptly decreases in thickness and is increasingly replaced by the rhodolith limestone facies towards the western lowland. The Upper Member is a large foraminifera grainstone/packstone. Boreholes can be correlated on the basis of lithostratigraphy and calcareous nannofossil biostratigraphy. Five nannofossil-datum levels show the Ryukyu Group to be $1.36 \sim 0.39 \mathrm{Ma}$.

The Ryukyu Group accumulated in a reefal to shelf environment where the water depth was increasing toward the west. At low sea level stand, the coral limestone facies extended for a distance westward and at high sea level stand, the rhodolith limestone facies was distributed widely in the area.

The unconformity between the Lower and Middle Members falls between $1.10 \mathrm{Ma}$ and 0.89 Ma. A number of unconformities, regressive sequences, and cooling episodes are recorded at this time in Japan. According to nannofossil-datum, the lowest rhodolith limestone facies of the Middle Member may be correlated with the oxygen isotope stages 25-23 of Williams et al. (1988), and the coral-rhodolith sedimentary cycles in the Middle Member are considered to be formed in response to glacial eustacy (oxygen isotope stages 26-16).
\end{abstract}

* 平成 5 年 6 月 11 日, 平成 5 年度石油技術協会春季講演会地質・探鉱部門シンポジウム「シーケンス層序学」にて講演

** 合同石油開発㑣 $\quad * * *$ 石油公団石油開発技術センター ****ジャパン石油開発條

Copyright (C) 1994, JAPT 


\section{1.はじめに}

炭酸塩岩は世界の油・ガスの $50 \%$ 近くを胚胎してい るとされ（Davies et al., 1988），地質時代・現世双方 の炭酸塩堆積物の研究により提唱された数多くの堆積モ デルは（例えば Wilson, 1975; James, 1984; Tucker and Wright, 1990), 油・ガスの探鉱・開発に多大の 貢献をしてきた（例えば Roehl and Choquette, 1985; Scholle et al., 1983)。近年, 比較的規模の小さな構 造・地震探相での識別が難しい構造にも着目されるよう になってきているという状況の中で，浅海成炭酸塩岩に はその油・ガス眝留岩としてのポテンシャルに期待が寄 せられている。從来の浅海成炭酸塩岩の堆積モデルはそ の多くがカリブ海,グレートバリアリーフ,ペルシャ海岸 地域など熱帯・非活動的縁包域にある現世堆積物の研究 に基づいて提唱されたものであった（例えば Bathurst， 1971; Purser, 1973; Davies et al., 1988)。

琉球列島は，亜熱帯・活動的縁辺域に位置すること， 水河性海水準変動に集約される第四紀という地球規模で の環境変動が起きている時期にサンゴ礁複合体堆積物の 形成が進行しかつ今なお形成されつつあること，沖縄卜 ラフの存在により陸源物質の影響をほとんど受けない純 炭酸塩堆積物からなることなどにより特徽づけられ，熱 帯・非活動的縁辺域とは異なった浅海成炭酸塩岩の堆積 モデルを提供し得る格好の場である。また最近非熱帯 性炭酸盐岩の形成に関する議論が盛んになりつつあり (Nelson，1988)，熱帯一温帯をつなぐ地域としても琉 球列島は着目される。このように異なった地質学的・海 洋学的条件下に㧍ける炭酸塩堆積モデル・続成モデルの 構築，さらには新たなる概念に基づく探鋐ターゲットの 開拓を目的として，石油公団開発技術センターでは沖縄 県宮古郡伊良部島地域（図 1）に扔いて次の上うな調查 を行ってきた：(1）コア採取・電気検層および露頭調查, （2）周辺海域における物理探査，(3) 周辺海域における 現世堆積物調查, 流況調查, (4) ボーリング坑井内にお ける地層水調查。本論ではこのうち主として（1）につ いて記す。すなわちコア試料並びに陸上露頭の観察に基 づき, 更新統琉球層群中の各岩相の層位的変化・水平的 変化の把握および石灰質ナン，化石による時間的枠組 みの構築を行い，現世堆積物調查の成果（辻ら，1989; 1993; Tsuji，1993）に基づいて各岩相の示す堆積環境 について論じる。そして堆積環境の変化が岩相分布を規 制する要因一第四紀の海水準変動一とどのように対応し ているかについての考察を行う。

琉球列島の最南部に位置する沖縄県宮古郡伊良部島に は浅海成石灰岩からなる更新統琉球層群が広く分布し，

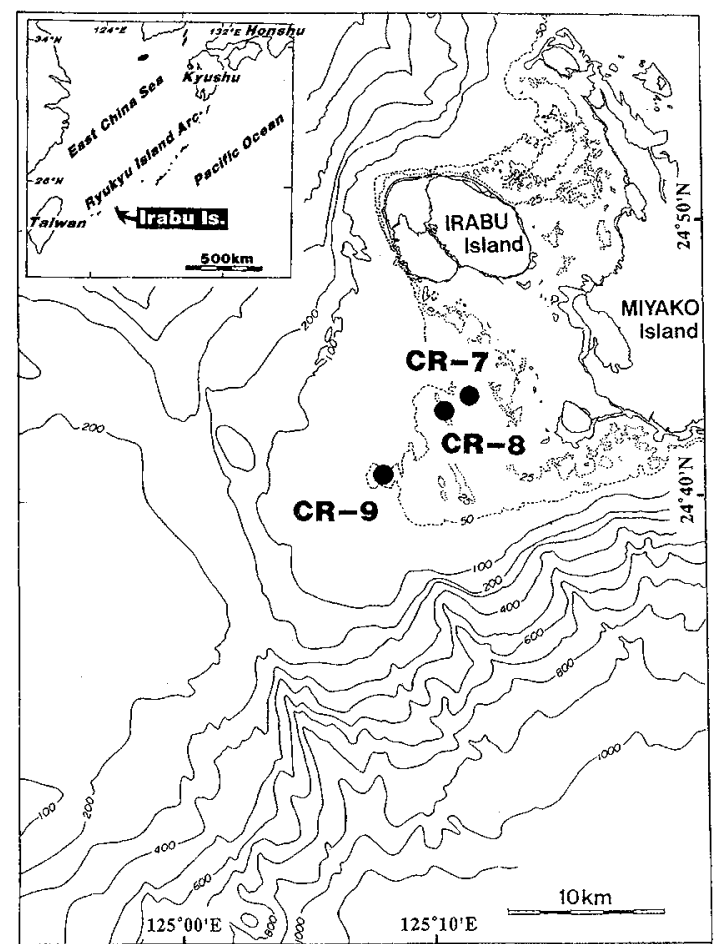

図 1 琉球列島，伊良部島の位置図

Doan et al. (1960)，矢崎 (1978)，中森（1982），佐渡 ら（1992）に上り岩石層序，微化石層序の解明が進んだ。 また Obata and Tsuji（1992）は地震探查記録を用い て, 第四紀の地史の変遷を論じている。一方近年, 琉球 列島に扔ける現世堆積物の研究が進展し（Iryu and Matsuda, 1988; Nakamori, 1986; 辻ら, 1989; 1993; Tsuji, 1993; 松田ら，1992；古田土・中川, 1993), 琉 球層群の婎積環境に関する詳細な議論がなされている （井龍・山田, 1991; 井龍・鈴木, 1990; 井龍ら，1992； Iryu，1992)。また，第四紀を細分したTakayama and Sato（1987）の石灰質ナンノ化石基準面を用いて, 本島の琉球層群においてもより詳細な時代論が可能となっ てきている（佐渡ら，1992）。このような現世堆積物研 究の進展と時間分解能の精度向上という背景の中で, コ ア試料を用いた岩石層序の確立という条件を備えた本島 の琉球層群は，海水準変動に対する炭酸塩岩の層相変化 を考究するに格好の対象である。

\section{2. 研究方法}

伊良部島域で掘削した坑井および露頭において琉球層 郡の岩石の記載 Embry and Klovan (1971) に従っ て行い,これに主要構成生物種名を付与した。時代決定 
表 1 伊良部島の琉球層群の堆積相

\begin{tabular}{|c|c|c|c|c|c|}
\hline Lithofacies & Rock Types & $\begin{array}{l}\text { Depositional } \\
\text { Environments }\end{array}$ & $\begin{array}{l}\text { Depth of } \\
\text { Deposition }\end{array}$ & Characteristic Constituents & Remarks \\
\hline \multirow{4}{*}{$\begin{array}{l}\text { coral } \\
\text { limestone } \\
\text { facies }\end{array}$} & $\begin{array}{l}\text { encrusting algal } \\
\text { flst } / \text { frst } / \text { bist }\end{array}$ & reef & $0 \sim 60 \mathrm{~m}$ & $\begin{array}{l}\text { * encrusting coralline algae } \\
\text { * encrusting bryozoans } \\
\text { foraminifers } \\
\text { * laminar hermatypic corals }\end{array}$ & $\begin{array}{l}\text { often accompanied } \\
\text { with bioclastic } \\
\text { gnst/pkst }\end{array}$ \\
\hline & $\begin{array}{l}\text { coral } / \text { flst } / \mathrm{rdst} / \\
\mathrm{frst} / \mathrm{bist} / \mathrm{bfst}\end{array}$ & $\begin{array}{l}\text { reef and sur- } \\
\text { rounding area }\end{array}$ & $0 \sim 60 \mathrm{~m}$ & $\begin{array}{l}\text { * hermatypic corals } \\
\text { (autochthonous, allochthonous) } \\
\text { * encrusting algae } \\
\text { * shallow benthonic formini- } \\
\text { fers (miliolids, Calcarina } \\
\text { spp., Baculogysina spp. } \\
\text { Marginopora spp.) }\end{array}$ & $\begin{array}{l}\text { accompanied with } \\
\text { bioclastic-benthonic } \\
\text { foraminiferal gnst/ } \\
\text { pkst }\end{array}$ \\
\hline & $\begin{array}{l}\text { quartz-bioclastic } \\
\text { gnst } / \text { pkst }\end{array}$ & reef/near reef & $0 \sim 60 \mathrm{~m}(?)$ & $\begin{array}{l}\text { * benthonic foraminifers } \\
* \text { sandstone/siltstone gravels } \\
\text { * quartz grains } \\
\text { * corals } \\
\text { * molluscs }\end{array}$ & $\begin{array}{l}\text { accompanied with } \\
\text { common coral frag- } \\
\text { ments }\end{array}$ \\
\hline & \multirow[t]{2}{*}{$\begin{array}{l}\text { bioclasic gnst } \\
\text { pkst/wkst }\end{array}$} & $\begin{array}{l}\text { inter reef } / \text { near } \\
\text { reef } / \text { back reef }\end{array}$ & $0 \sim 90 \mathrm{~m}$ & $\begin{array}{l}\text { * benthonic foraminifers } \\
\text { (miliolids, Calcarina spp., } \\
\text { Baculogypsina spp. Marg } \\
\text { inopora spp.) } \\
\text { * coralline algal fragments } \\
\text { * Halimeda spp. } \\
\text { * molluscs }\end{array}$ & \\
\hline \multirow{4}{*}{$\begin{array}{l}\text { rhodolith } \\
\text { limestone } \\
\text { facies }\end{array}$} & & $\begin{array}{l}\text { open outer } \\
\text { shelf }\end{array}$ & $60 \sim 200 \mathrm{~m}$ & $\begin{array}{l}\text { * benthonic forminifers (Am- } \\
\text { phistegina spp.) } \\
\text { * bryozoans } \\
\text { * molluses } \\
\text { * planktonic foraminifers }\end{array}$ & \\
\hline & $\begin{array}{l}\text { Halimeda flst } / \\
\text { rdst } / \text { pkst }\end{array}$ & open shelf & $50 \sim 80 \mathrm{~m}(?)$ & * Halimeda spp. & \\
\hline & $\begin{array}{l}\text { rhodolith flst } / \\
\text { rdst }\end{array}$ & $\begin{array}{l}\text { open outer } \\
\text { shelf }\end{array}$ & $60 \sim 150 \mathrm{~m}$ & $\begin{array}{l}\text { * rhodoliths } \\
\text { * benthonic foraminifers } \\
\text { (Amphistegina spp., } \\
\text { Cycloclypeus spp.) } \\
\text { * bryozoans }\end{array}$ & \\
\hline & $\begin{array}{l}\text { large formini- } \\
\text { feral flst } / \text { gnst } / \\
\text { pkst }\end{array}$ & $\begin{array}{l}\text { open outer } \\
\text { shelf }\end{array}$ & $60 \sim 150 \mathrm{~m}$ & $\begin{array}{l}\text { * large benthonic foraminifers } \\
\text { (Cycloclypeuts spp., Hetero- } \\
\text { stegina spp.) } \\
\text { * bryozoans }\end{array}$ & $\begin{array}{l}\text { accompanied with } \\
\text { bioclastic gnst } / \\
\text { pkst/wkst }\end{array}$ \\
\hline
\end{tabular}

には石灰質ナンノ化石を用い，各基準面とその年代值は Sato and Takayama (1992) による。また本島周辺 海域の現世堆積物の分布データ（辻ら，1989；1993）に 基づき, 琉球層群の各岩相の堆積環境・水深を定めた (表 1)。

\section{3. 岩石層序}

伊良部島の地形は東部高地帯と西部低地帯に区分され る（図 2)。東部高地带には 3 段の平坦面が発達し，そ の東縁は断層崖により限られる（矢崎，1978）。更新統 琉球層群は，鮮新統島尻層群を傾斜不整合に被って島全 域に分布している（図3）。不整合面は島の北部では北 西に，中部では西に，南部では南西方向にいずれも $1^{\circ}$
内外之緩く傾斜し（図 4), 琉球層群の各層は不整合面 と調和的に西方向の成分を持って緩傾斜（1 ${ }^{\circ}$ 内外）し ている。

琉球層群は, 層厚 50-110m, 2つの不整合により下 部層・中部層・上部層に 3 分され（風 3), サンゴ flst $/ \mathrm{rdst} / \mathrm{frst} / \mathrm{bist}^{(i)^{1)}}$, 石灰藻球 flst $/ \mathrm{rdst}$, 生物砕屑 性 gnst / pkst / wkst，被覆型石死藻 flst / bist，大 型有孔虫 rdst $/ \mathrm{flst} / \mathrm{gnst} / \mathrm{pkst,}$ 石英一生物碎屑性 gnst / pkst, Halimeda flst/rdst が識別される（表 1)。岩相はサンゴ石死岩相と石灰藻球石灰岩相とに大き

注 1) wkst: wackestone, pkst: packstone, gnst: grainstone, flst: floatstone, rdst : rudstone, bfst: bafflestone, bist : bindstone, frst: framestone. 


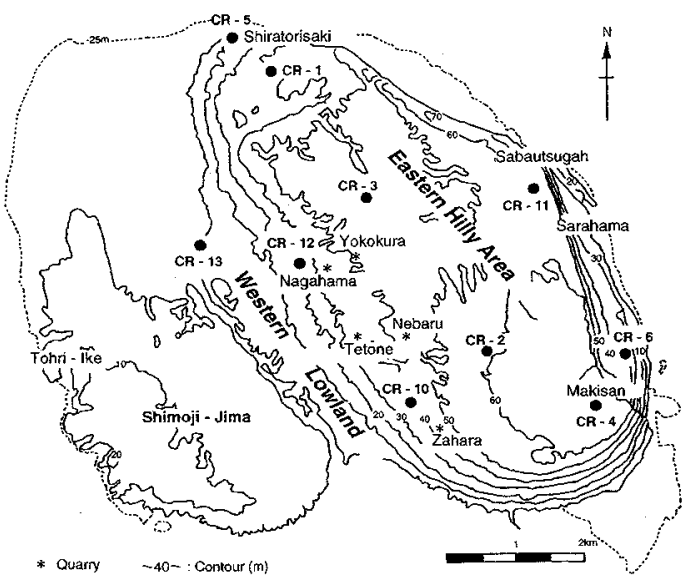

図 2 伊良部島の坑井・採石場の位置図

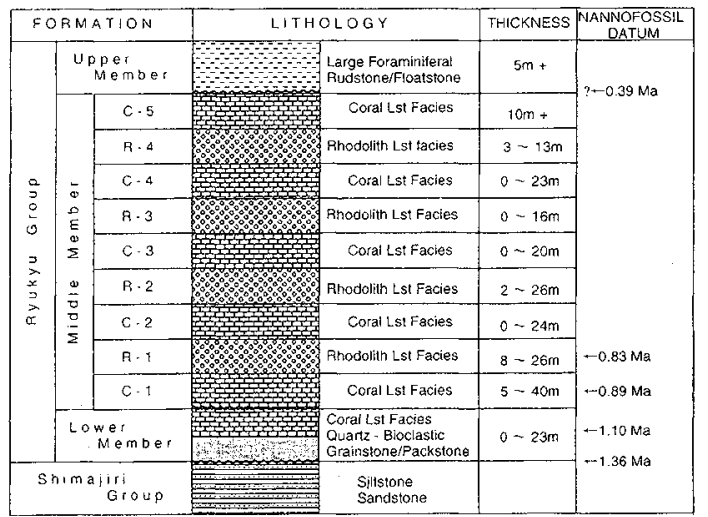

図 3 伊良部島の琉球層群の層序

く2分され，その繰り返しからなる堆積サイクルが 5 回認められる（図 3)。サンゴ石灰岩相はサンゴ flst／ frst を主体とし生物砕屑性 gnst／pkst 亡被覆型石灰藻 bist flst を伴い, 石灰藻球石灰岩相は石灰藻球 flst $/$ rdst を主体とし大型有孔虫 flst $/ \mathrm{rdst}$ と生物砕首性 gnst / pkst / wkst を伴う。岩相は側方に大きく変化し, 東部高地帯ではサンゴ石灰岩相が, 西部低地帯では石灰 藻球石灭岩相が卓越する（困 4,5)。

\section{1 琉球層群下部層}

本部層は北西部の CR-1, 5 のみで認められる。CR-1 では, 島层層群を不整合に被って石英一生物砕屑性 gnst / pkst が基底層として約 $3 \mathrm{~m}$ の厚さで発達してい る（図6）。この石英一生物砕屑性 gnst／pkst は島尻層 群に由来する砅之石英粒子を頻繁に含み, 厚さ数十 $\mathrm{cm}$ のサンゴー石灰藻球 bist が数層準で発達し，バグ中に は赤褐色堆積物がしばしば認められる。本石灰岩の上位

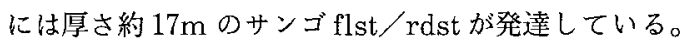

この石灰岩は厚さ $40 \sim 50 \mathrm{~cm}$ のサンゴ bfstを境として 岩相が変化し, 下位の $11 \mathrm{~m}$ ではサンゴ flst が主体を なし，上位 $6 \mathrm{~m}$ ではサンゴ rdst が増加する。サンゴ flst $/$ rdst $/$ frst の基質は細片化したサンゴ，石灰藻の 他, 二枚貝, 巻貝, ウ二骨針などからなる生物砕屑物 gnst / pkst / wkst からなり，石英砂粒子を含む。中部 層との不整合面の直下には，二次的な孔隙・再結晶化し た方解石などの溶解構造が発達し，バグ中にはラテライ 卜質赤褐色堆積物が特に多く認められる。

\section{2 琉球層群中部層}

本層はサンゴ石灰岩相を主体とするユニット C-1 5 上石灰藻球石兏岩相を主体とするュニットR-1 4 の繰 り返しからなり，北西部の CR-1, 5 では下部層と溶解 不整合で接し，他の坑井（CR-2, 3, 4, 6, 10, 11, 12, 13) では島层層群を直接不整合に被う（図4）。中軸部の CR-1, 2, 3, 5 ではサンゴ石灰岩相と石死藻球石灭岩相 の繰り返しが明瞭で,この堆積サイクルにより各坑井の 岩相対比が可能である。しかし西部〜南部の CR-10, 12, 13 では石灰藻球石死岩相が卓越し, 東部の CR-4, 6, 11 では逆にサンゴ石灰岩相が優勢となるため，堆積サイク ルの認定が困難となる場合が多い。

ユニット C-1 : 北西部の CR-1 では有孔虫に富む数十 $\mathrm{cm}$ の厚さの石英一生物砕屑性 gnst / pkst が基底部に 発達し，その上位にはサンゴ flst／frst, 被覆型石死藻 bist 执よび生物砕屑性 gnst／pkst が約 $20 \mathrm{~m}$ の厚さで 発達している。北西部の CR-1, 5 以外の坑井では, 島 尼層群起源の円碟と石英粒子を含む厚さ数十 $\mathrm{cm}$ 数 $\mathrm{m}$ の石英一生物砕屑性 gnst／pkst が琉球層群の基底相之 発達し, 上方へサンゴ flst $/ \mathrm{frst}$ 亿漸移する。ラテラ イト質の赤褐色堆積物がバグ中に頻繁に認められる。西 部の CR-12, 13 ではサンゴ flst 中のサンゴは破片化し たものが多く生物砕屑性 gnst／pkst八と漸移するのに 対し, 東部の CR-2, 4,6 ではサンゴの量が多く, 現地 性のあのがしばしば認められる。CR-1, 5 では, 本ュニッ ト中に被覆型石灰澡 bist の発達が認められる。

ユニットR-1: 西部の CR-12, 13 では $7 \mathrm{~m}$ 前後の均 質な石灰藻球 flst/rdst からなるのに対し，中軸部の CR-1, 2, 3 では被覆型石疢藻 bist と生物砕首性 gnst pkst を挟在する（図 7)。北西端の CR-5 では厚さは 20 $\mathrm{m}$ を超え, 中部に若干量の赤褐色堆積物を伴う。南部 の CR-10では, 本ュニット上位のュニット C-2 の発達 が不明瞭で, 生物砕屑性 gnist pkstを経て次のサイク ル(ユニットR-2) の石死藻球 flst / rdst が発達して いる。東部〜南東部の CR-4, 6, 11 では本ュニットの発 達は筫弱で，サンゴflstにより隔てられた数枚の石灰 藻球 flst と生物砕愿性 gnst／pkst の薄層として本ュニッ 


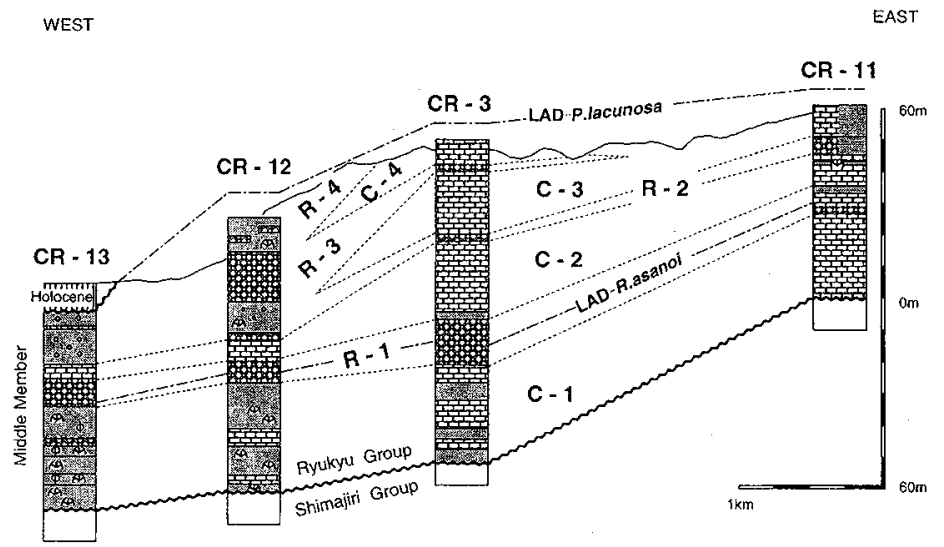

(1) 東西断面 I-CR-11，3，12，13-

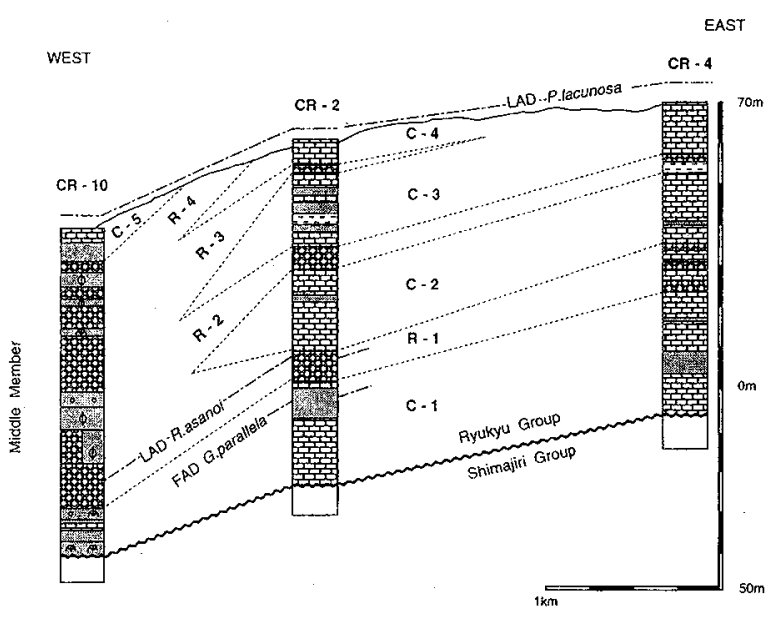

(2) 東西断面 II-CR-4，2，10-

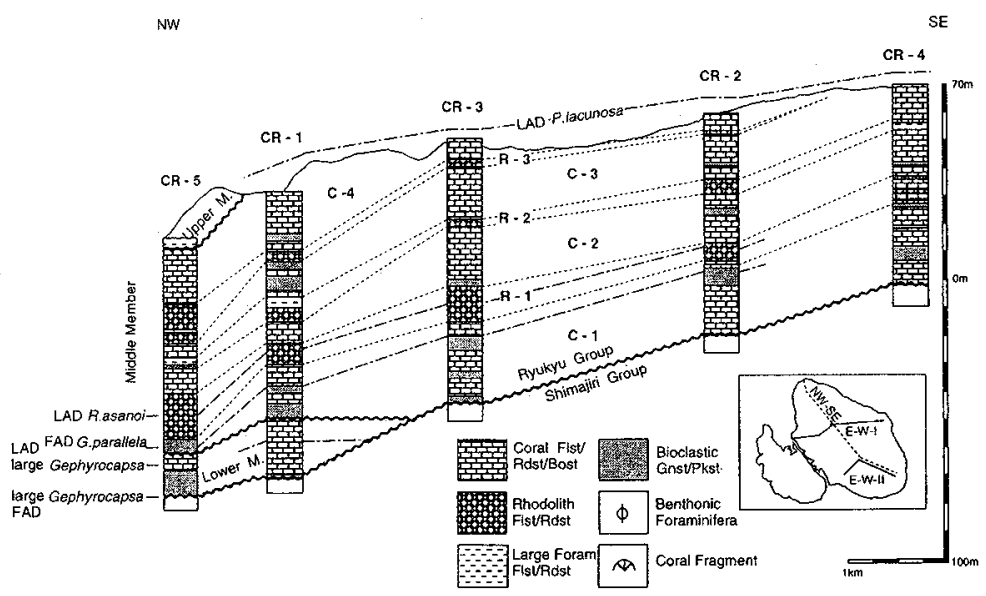

(3) 北西一南東断面-CR-5, 1, 3, 2, 4-

図 4 琉球層群の坑井柱状対比図 


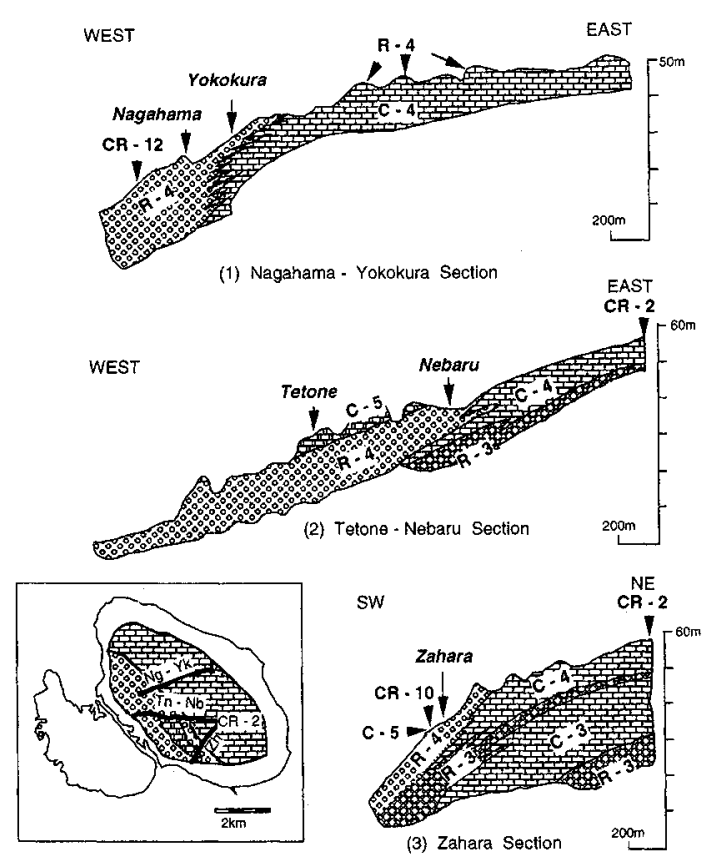

図 5 琉球層群中部層の地質断面図－伊良部島東部 高地帯西側斜面付近一

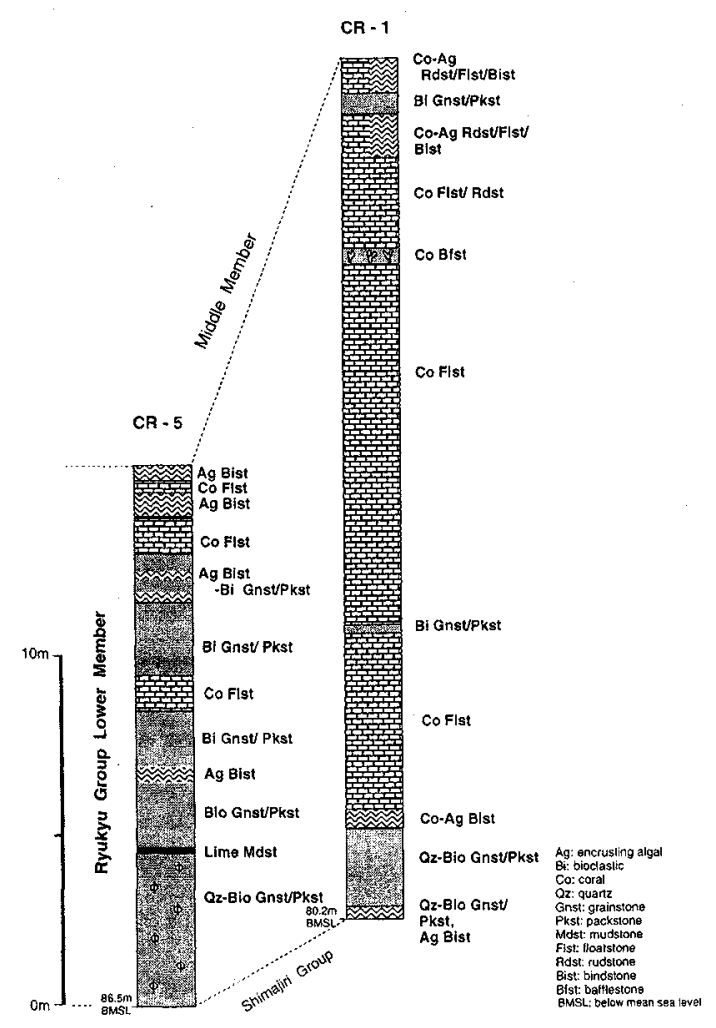

図 6 琉球層群下部層の坑井柱状図-CR-1, 5-
トは識別される。

ユニットC-2：サンゴ flstを主体とし，サンゴ frst, 被覆型石灰藻一サンゴ bist，生物砕屑性 gnst／pkst を 伴う。中央部から東部の CR - 2, 3, 4, 11 では 18〜 $24 \mathrm{~m}$ と厚く発達するが, 北西部の CR-1, 5 では $10 \mathrm{~m}$ 内外に, 西部の CR-12, 13 では 2 6m に薄化し，CR-10では認 められない。東に向かってサンゴ flst 中のサンゴの量 は多くなり，また現地性のサンゴの比率む高くなる。西 部ではサンゴ flst はサンゴ混じりの生物砕屏性 gnst／ pkst 入と潮移する。本ュニット下部では一般にサンゴ の量が少なく生物研屑性 gnst／pkst と漸移的であるが, 上部に向けてサンゴの量が増加するととすに, サンゴー 石灭藻 frst / bist が増加する。

ユニットR-2: 石灰藻球 $\mathrm{rdst} / \mathrm{flst}$ と大型有孔虫 flst /gnst/pkstにより特徴づけられる。中軸部から東部 (CR-1, 2, 3, 4, 5, 6, 11) では, 2 5m と比較的薄いが 坑井間で追跡可能である。西部〜南部の CR-10, 12, 13 では本ユニットの上下限を規定するサンゴ石灰岩相の発 達が欠除〜貧弱であるが, 大型有孔虫 rdst／flst～有孔 虫 gnst $/ \mathrm{pkst}$ を鍵層として本ュニットを認定すること ができる。

ユニットC-3：サンゴ flst と生物砕屑性 gnst / pkst を主体としサンゴー被覆型石灰藻 flst／bist を頻繁に伴 う。CR-3 では中部に厚さ $1.5 \mathrm{~m}$ の Halimeda-大型有 孔虫 flst $/ \mathrm{rdst}$ が発達する。中軸部の CR-1, 2, 3 では 厚さ $10 \mathrm{~m} \sim 20 \mathrm{~m}$ ，東部の CR-4,6であ少なくとも $14 \mathrm{~m}$ の厚さを持つ。北西部の CR-5, 南部の CR-10 では, 本ユニットは数 $\mathrm{m}$ 以下に薄化し, 西部の CR-12, 13 で は消隇している。

ユニットR-3: 北西部の CR-1, 5 では数枚の有孔虫 gnst / pkst を挟む石灰藻球 flst / rdst が $4 \sim 15 \mathrm{~m}$ と比 較的厚く発達している。中央部の CR-2, 3 では $1 \sim 2 \mathrm{~m}$ に薄化し，東部の CR-4, 6, 11 では認められない。西部 のCR-12, 13 では，上下限を画するサンゴ石夷岩相を 欠くため上下位のユニットR-2, R-4 との区別が困難で ある。

ユニット C-4：サンゴー被覆型石灰澡 flst を主体とす る本ユニットは東部高地带に広く分布し（図5), 中軸 部の CR-1, 2,3,5 では 6 22m と厚く発達する。東部 の CR-4, 6, 11 では削剥のため, 西部の CR-12, 13 では 尖滅して本ユニットは認められない。横倉採石場では本 ユニットは $10 \mathrm{~m}$ 以上の厚さで，根原採石場では上下を 石灰藻球石灰相に挟まれて数 $\mathrm{m}$ の厚さで発達している （図 8)。白鳥崎周辺では本ユニット最上部, 上部層との 不整合面の直下に現地性のサンゴを含むサンゴ frst／ flst が発達している。 


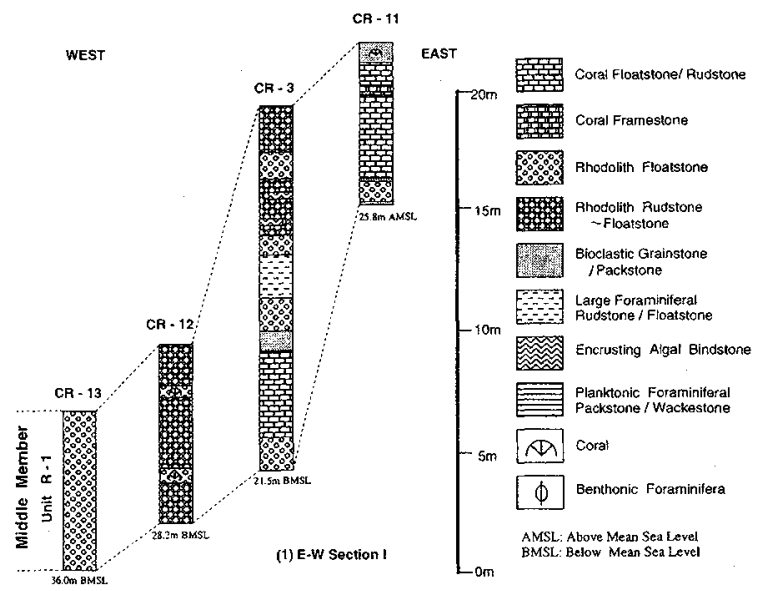

(1) 東西断面 I-CR-11, 3, 12, 13-
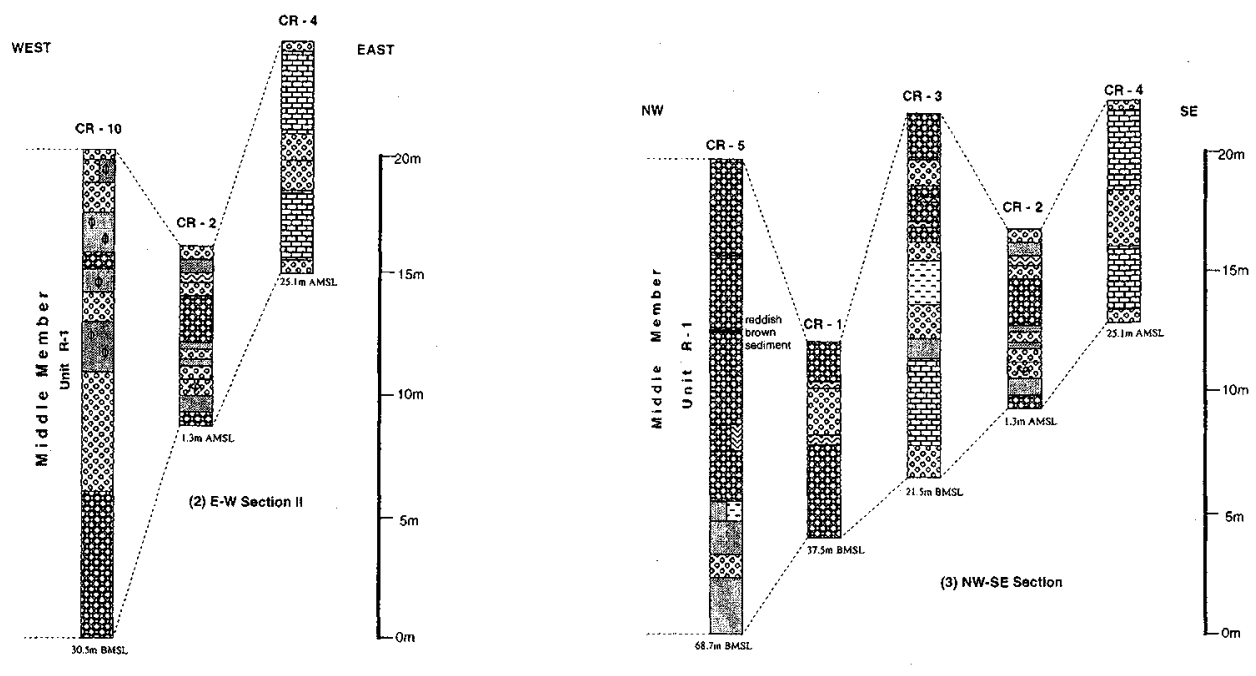

(2) 東西断面 II-CR-4, 2, 10-

(3) 北西一南東断面－CR-5，1，3，2，4-

図 7 琉球層群中部層, ユニットR-1 の坑井柱状対比図

ユニット R-4 : 長浜採石場では石灰藻球 flst/rdst を 主体とする本ュニットが $16 \mathrm{~m}$ 以上の厚さで発達してい る。しかしその $100 \mathrm{~m}$ 東方の横倉採石場では，その上部 に長浜採石場上部の石灰藻球 flst / rdst と大型有孔虫 flst／gnst に対応する岩相の発達をみるが, 中下部はサ ンゴ flst が卓越し急激な岩相の側方変化を示している （図 8)。根原採石場には石灰藻球 flst／rdst，石灰藻球 とサンゴをまじえた有孔虫 gnst／pkstからなる本ュニッ トが少なくとあ 8～9m の厚さで分布している。東部高 地帯に点在する石灰藻球 flst／rdst の小露頭は本ュニッ トに含まれるものと考えられる（図 5)。西部低地帯〜 下地島に広く分布する石灰藻球 flst / rdst, CR-10,12 の坑井上部の石灰澡球 flst ・ 生物砕䖉性 gnst / pkst な
ども本ユニットに対比される可能性が高いが，上下位の サンゴ石灰岩相の発達が悪く確実な対比は困難である。

ユニット C-5: 手登根採石場では本ュニットは $5 \mathrm{~m}$ 以 上の厚さのサンゴ flst/frst かららる（図 8)。下半部 はサンゴ flst を主体とし, 上半部はサンゴ frst と被覆 型石死藻 bist の発達が頻繁となる。本ユニットは中部 層最上位のサンゴ石死岩相で, 東部高地帯の西側斜面に 外座層として分布し（図5), 坑井ではCR-10 の最上部 でのみ, 生物砕屑性 gnst／pkstからなる本ユニットが 認められる。CR-10東方では本ュニットが南西方向に $3 \sim 4^{\circ}$ 傾斜しているのが認められる。

\section{2 琉球層群上部層}

北西端の CR-5 および白鳥崎周辺のみで認められる。 


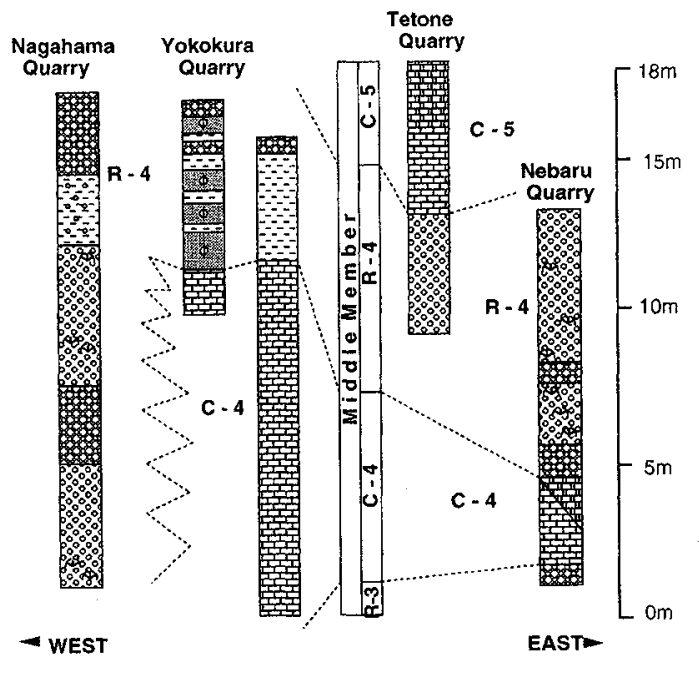

L.egend-Ser Fig.7

Amphistegina を主体とし, Cycloclypeus, Operculina, Baculogypsina, Marginoporaなどを伴う 大型有孔虫 $\mathrm{rdst}$ からなり層厚は $4.5 \mathrm{~m}$ 以上，基質の細 粒部の発達が悪く多孔質である。CR-5ではュニットR4，C-5 を欠いて，本部層がユニットC-4 直接不整合 に被っている。露頭では不整合面は凹凸に富み，見掛け 上，北～西方向に傾斜し，白鳥崎東侧で洁古土壌由来之 考えられる赤褐色粘土層の発達が観察される。

\section{4. 石灰質ナンノ化石層序}

約 600 個の琉球層群のコア試料を高山（1978）の方法 に準じて処理し，ほほ半数の試料からナンノ化石の産出 をみた。鑑定は光学顕微鏡を用いて倍率 $\times 1500$ で行い, 一部の小型種については走查型電子顕微鏡観察を行った。 ナンノ化石の大部分は石灰藻球 $\mathrm{rdst} / \mathrm{flst}$ の基質部 （生物碎屏性 gnst／pkst／wkst）加ら産出し，溶解之

図 8 琉球層群中部層, ユニット $\mathrm{C}-4$ および $\mathrm{R}-4$ の柱状図一長浜, 横倉, 手登根, 根原採石場一
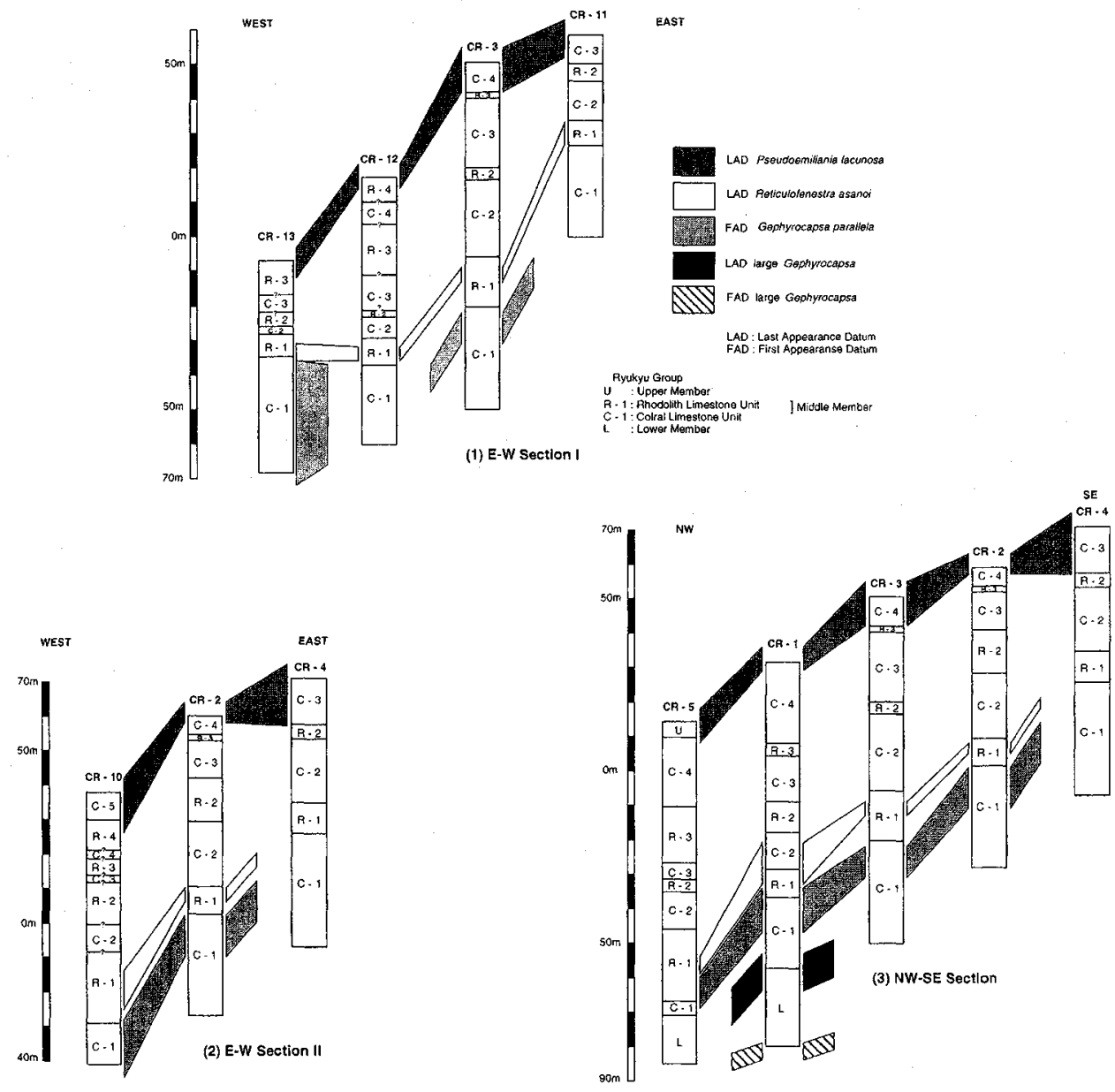

図 9 各坑井における石灰質ナン八化石基準面の層位的位置 


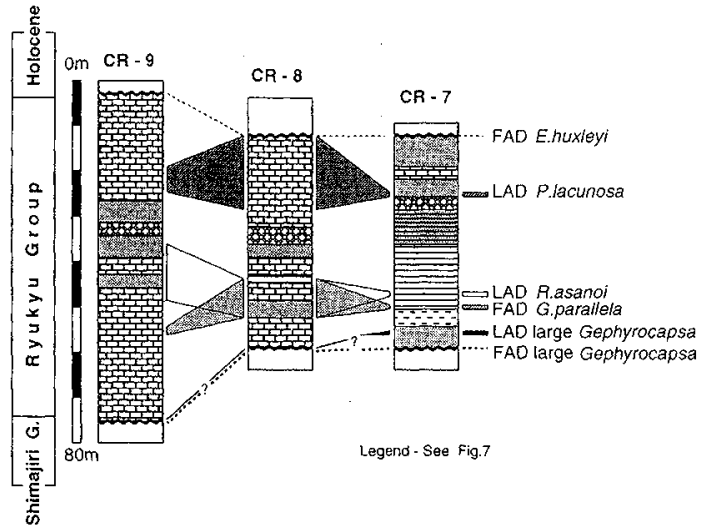

図 10 伊良部島海域の坑井の岩相之石灰質ナン/化 石層序-CR-7, 8, 9-

過成長のため保存状態は悪い。比較的保存のよいナン， 化石をほぼ連続的に産する海域の CR-7 参考しして, 島上のナンノ化石層序に関して検討した結果(悯 9，10), 本地域の琉球層群の堆積年代は $1.36 \sim 0.39 \mathrm{Ma}$ の間にあ る。

Gephyrocapsa spp. (large form) の初産出面 (1.36Ma) と終産出面 (1.10Ma): 本種の産出は CR-1 の下部層に限られ，ナンノ化石が全く検出されなかった CR-5 の下部層を議論から外すと, 岩石層序の結果の “下部層は CR-1，CR-5 のみで認められ，他の坑井では 中部序が島尻層群を直接不整合に被う”に符号する。 CR-7でも本種の産出は琉球層群基底部に限られ，本地 域における琉球層群の堆積が 1.36〜1.10Ma に開始した ことを示している。本種の終産出面は下部層と中部層を 隔てる不整合の中に含まれる可能性がある。

Gephyrocapsa parallela の初産出面 (0.89Ma): CR-1, 2, 3 ではユニット C-1 上部に, CR-5 ではュニッ 卜 $\mathrm{C}-1$ 上部〜ュニット R-1 下部に本基準面は認められ る。

Reticulofenestra asanoi の終産出面 (0.83Ma): 本基準面は中軸部から西部の坑井ではユニットR-1 中 の石灰藻球 rdst $/ \mathrm{flst}$ の中に, 東部の CR-11 では同卫 ニット中のサンゴ flst／frstの中にあり，岩相の境界と 斜交している(図 4)。

Pseudoemiliania lacunosa の終産出面 (0.39Ma): 島上のいずれの坑井においても $P$. lacunosa は中部層 最上部まで産出し，上部層からはナン/化石が全く検出 されなかったため，本基準面を島上の坑井中に認定する ことはできなかった。海域の CR-7では坑井上部に本基 準面が認められる。

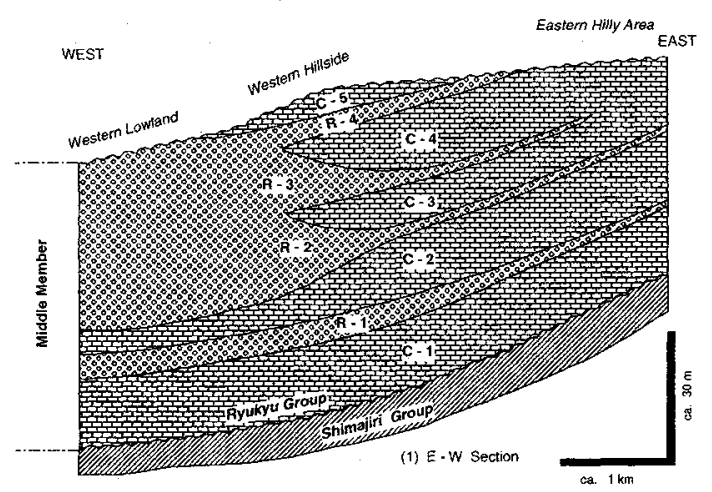

(1) 東西断面

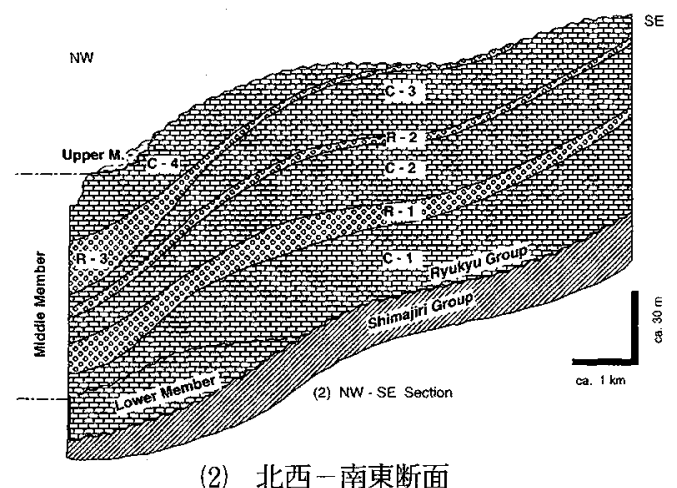

図11伊良部島の琉球層群の層序概念図

\section{5. 考察}

\section{1 琉球層群の堆積環境}

伊良部島の琉球層群を構成する 7 タイプの石灰岩の堆 積環境は，本島周辺海域の現世堆積物（辻ら，1989; 1993）との比較により，表1のようにまとめられ，サン ゴ石灰岩相は水深 $0 \sim 60 \mathrm{~m}$ の島棚内側 礁域の堆積物 (礁相), 石灰藻球石灰岩相は水深 $60 \sim 150 \mathrm{~m}$ の島棚外側 の堆積物（島棚相）に対応する。琉球層群中部層は礁相 と島棚相の繰り返しからなるが，島の東部では礁相が優 勢であり，西部では島棚相が卓越している(図 11)。ま たサンゴ flst から石灰藻球 rdst／flst へという岩相の 東西方向での变化が, Reticulofenestra asanoi の終 産出面上に抢いて認められ（図4）, 上述の堆積相の側 方変化の様相を明示している。さらに各岩相の側方変化 の詳細をみると, 礁相一島棚相という堆積相の変化とと あに次のような変化が認められる。（1）サンゴ flst 中 のサンゴの量は東部で多く，西部ではサンゴ flst は生 物砕首性の gnst／pkst へと容易に移化する。（2）サン ゴ frst の発達は東部で顕著である。(3) 石灰澡球 flst の石灰藻球の量は西部で多く, 石灰藻球 rudstone 
は東部ではまれであるが，西部では顕著な発達を示す。 （4）有孔虫 rdst/gnst は中部〜西部で頻繁に発達する。 このような礁相加ら島棚相への変化に集約される堆積相 の東西方向での变化は, 東部高地帯の西縁部において急 激である(例えば根原採石場, 横倉一長浜採石場; 図 5)。 堆積相およびその変化様式, 西方向に緩倾斜する島尻一 琉球層群間の不整合面の形態, 不整合面之調和的な琉球 層群の走向傾斜などの点加らみて, 東に浅くやや急傾斜 の部分をへて西方に徐々に深くなる島棚上に，本島の琉 球層群牥形成されたあのと考えられる。

\section{2 琉球層群の堆積史}

更新世前期，1.36 1.10Ma の間に伊良部島の琉球層 群は傾動した島尻層群上に堆積を開始した。宮古島に分 布する島尻層群最上部の時代については意見の相違があ るが (Ujiie and Oki, 1974; 中森, 1982), 中森 (1982) の見解をとると (1.91 1.66Ma), 島尻層群は長く見積 むって約 80 万年の間, 変形・隆起・削剥を受け, その 後全く堆積レジメの異なる琉球層群が形成されるに至っ た。本島南方の海域にある CR-7においてる時代的に下 部層に相当する岩石が礁成の生物研屑性 gnst / pkst で あることからみて，少なくとも本島北西端の CR-5 から CR-7 に至る南北 14 15km の地域は, 琉球層群堆積開 始時には水深が $60 \mathrm{~m}$ 以下の島棚内側〜礁域もしくは陸 域にあったるのと考えられる。

下部層において石英一生物研屏性 gnst /pkst からサ ンゴ flst，さらにサンゴfrstへと上方変化する岩相は （図 6)、海面下に没した島尻層群上に石灰質の底質が形 成され続いて本格的な礁へと発達する過程を示すすのと して注目される。グレートバリアリーフの裾礁において る，完新世の海水準上昇に対応して非炭酸塩堆積物加ら なる基盤を被って礁成の䂶屑性石灰岩が発達し, その上 位にサンゴの framework を持っ石灰岩が発達してい るのが報告されている(Davies and Hopley, 1983)。

続いて下部層一中部層間の不整合が古土壤を伴うこと に示されるように，島域は広範にわたって陸化したもの と考えられる。不整合の時期は $1.10 \sim 0.89 \mathrm{Ma}$ の間に入 り, $1 \mathrm{Ma}$ ごろに本邦各地で認められる不整合・堆積物 の粗粒化・生物群集の浅海化/寒冷化 (Sharma et al., 1989 ; 佐藤・高山, 1990）に対比される可能性がある。

中部層は島の北西部では下部層を, 島の他の地域では 島尻層群を直接に被って, $1.10 \sim 0.89 \mathrm{Ma}$ に堆積を開始 した。中部層の堆積サイクルを構成するユニット R-1・2・ $3 \cdot 4$ の間には, 岩相上の顕著な差異は認められず, ユニッ 卜R-1 R-4 は各々同程度の水深で形成されたものと考 えられる。ユニット C-1 C-5 も同様である。第四紀の 酸素同位体变動曲線（Williams et al., 1988） の高海
水淮期を示すピークが，時代とともに上昇する傾向が認 められないことからみて，堆積物による埋積にほほ均衝 する大きさの沈降が，島全体として起きたものと考元ら れる。その後, 中部層一上部層間の不整合に示される海 水準の大幅な低下と, 大型有孔虫 rdst 加らなる上部層 の形成に示される海水準上昇が，少なくとも 1 回づつ起 きたものと考元られる。

\section{3 サンゴ石灰岩相の形成と海水準変動}

琉球層群の岩相の側方変化は, その時点における堆積 環境・堆積深度の違いに起因し, 岩相の層位的变化は相 対的な海水準の変動に関連しているものと考えられる。 しかしサンゴ石灰岩相か酸素同位体の変動に示されるよ うな汎世界的な海水準変動の中のいずれのステージの産 物であるかは與味深い問題である。石灰藻球石灰岩相一 サンゴ石灰岩相という堆積サイクルをそのまま汎世界的 な海水準の高低を反映するものとしてとらえることがで きるのか。あるいは石灭澡球石灭岩相, サンゴ石灭岩相 と屯に汎世界的海水準変動の中の高海水準時の産物であ り低海水準時には堆積は起こらない状況にあったのか。 また海進期, 海退期の堆積物はシークエンスの中にどの ように認定されるのか。

このように多くの問題がある中で, 汎世界的な高海水 準時における石灰藻球石灰岩相の形成，低海水準時にお けるサンゴ石灰岩相の形成を支持するものとして下記が 挙げられる。（1）もし琉球層群中部層のサンコ石灰岩相, 石灰漟球石灰岩相がともに高海水準時の産物であるなら ば，低海水準時には島の東部を中心として大規模な不整 合が認定されるはずである。しかし中部層中に離水を指 示する事実は認められない。(2) 琉球層群中部層の堆積 年代は $1.10 \sim 0.39 \mathrm{Ma}$ の間に入り，海域の坑井における 琉球層群の堆積年代加らみても（図 10）, 中部層の形成 には数十万年を要したものと考えられる。従って中部層 の堆積サイクル全体を数万年オーダーの 1 回の高海水準 期の中に含めてしまい，上下の不整合を低海水準期の産 物とする考え方は夕イム・スパンの点から支持されない。 (3) Fairbanks（1989）によるとバルバドス島沖合い では最終水期の最盛期にはサンゴ石灰岩相が発達してい るのに対し，現在の海底表層には砂磞相が形成され，低 海水準時二礁相, 高海水準時=沖合い相という堆積図式 を示している。

琉球層群中部層が更新世の中ごろの数十万年間に形成 された堆積物であり，その当時の沈降運動が堆積物によ る埋積と均衝する程度のむので水河性海水準変動に比し てはるかに緩慢なものであるならば，中部層の各堆積サ イクルを水河性海水準変動に対応させることは十分な妥 当性があるすのと考元られる。以下, 酸素同位体变動か 


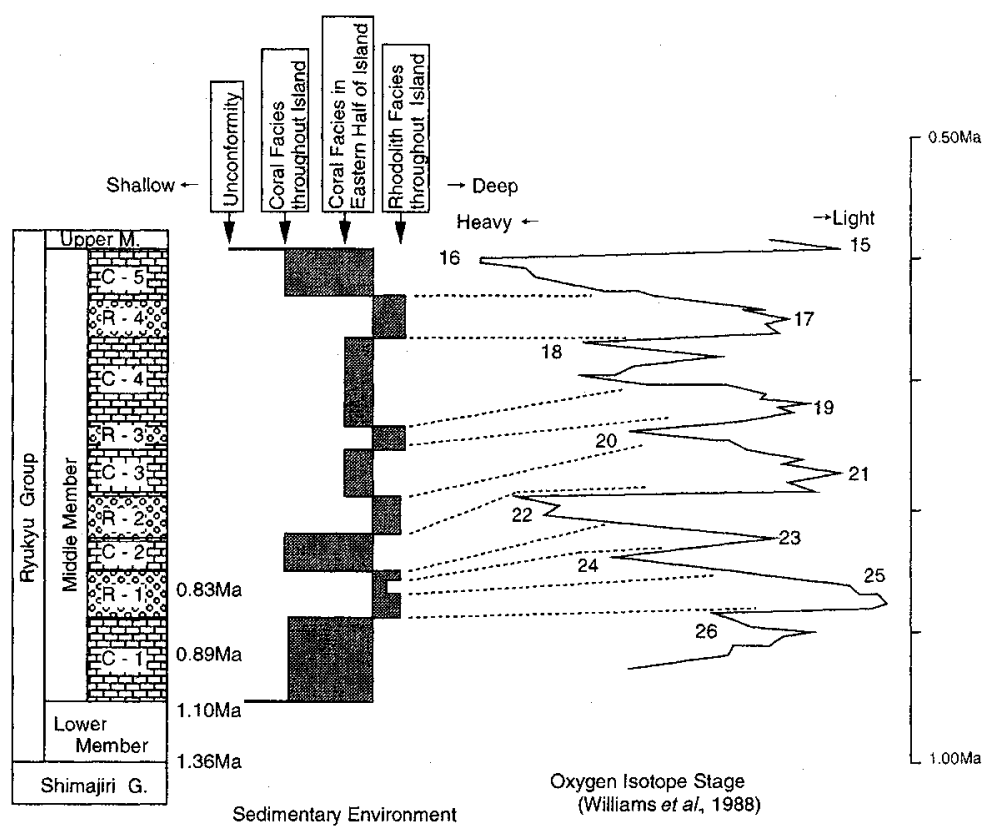

図 12 琉球層群中部層の堆積サイクルと酸素同位体ステージ

らみて汎世界的に海水準が低下したとされる時期には礁 相（サンゴ石灰岩相）が，海水準が上昇したとされる時 期には島棚暞（石灰藻球石灰岩相）が形成されたとの前 提の下に中部層の堆積サイクルと酸素同位体ステージと の対比を行った（図 12）。

$0.83 \mathrm{Ma}$ のナンノ化石基準面はいずれの坑井において あユニットR-1 の中部に認められる。ユニットR-1の 中部には，島の東部ではサンゴ flstが (CR-11), 中軸 部では被覆型石灰藻ーサンゴ bist が（CR-1,2,3），あ るいは赤褐色堆積物が（CR-5）認められ，ユニット R-1 中において香層位的に深 $\rightarrow$ 浅 $\rightarrow$ 深という堆積環境の 変化があったことを示している（図7）。島の西部では このようなユニットR-1内での岩相の層位的変化は認 められず，ュニットR-1をと扎して石灰藻球 flst／ rdst が卓越している。以上よりユニットR-1 の下部は Williams et al. (1988) のステージ 25 に，中部はス テージ 24 に，上部はステージ 23 に対応するものと考え られる。すなわちステージ 25 の高海水準時には現在の 島全域が石圧薄球 flst/rdst を形成するに足る水樑下 にあったが，ステージ24の低海水準時には島の東部で は水深 $60 \mathrm{~m}$ 以下となりサンゴ flst が形成され，中軸部 でも海水準低下に対応して石灰藻球 flst／rdst から被 覆型石兏藻一サンゴ bist へと岩相变化したが，西部で はこのステージ 24 にあってあ依然として水深は $60 \mathrm{~m}$ を 超え石灰藻球 flst／rdst が引き続き形成された。ステ
ージ23の高海水準時には再び島中軸部まで石灰藻球 flst / rdst 形成の場となったが，東部では水深は $60 \mathrm{~m}$ を超えることははとんどなくおおむねサンゴ flst の形 成が続行した。ただ CR-1 のユニットR-1 最上部での サンゴ flst から生物砕屑性 gnst/pkst への岩相変化, CR-4, 6 のユニットR-1 上部における石灰藻球 flst の 発達はステージ 23 の海水準上昇を反映しているすのと 考えられる。

ステージ 22 の低海水準期には島は南部の CR-10を除 くほほ全域にわたってュニットC-2 形成の場となり， 酸素同位体の変動に表されているようにステージ 22 の 海水準の低下が極めて大きかったことを示しているもの と考えられる。

その後 $21,20,19,18,17$ の各ステージに対応して島の 中軸部から東部では石灰藻球石灰岩相とサンゴ石灰岩相 が交互に形成されたが，西部ではステージ20，18の低 海水準時にも石死藻球石灰岩相の形成が続行しサンゴ石 灰岩相の発達をみなかった。これはステージ20,18の 海水準低下の規模が，ステージ 22 に比して小さかった こと，あるいは東西での堆積環境の分化がより大きくなっ てきたことを示しているあのと考えられる。

ステージ 16 (約 $0.6 \mathrm{Ma}$ ）に至り島域全体は再びサン ゴ石灭岩相の形成される島棚内側〜礁域と化し, 島の中 央部〜東部は離水した可能性もある。CR-10のコア最 上部および東部高地带西側斜面に外座層として分布する 
ユニットC-5 はこの低海水準時の堆積物を代表するも のである。下地島西端の通り池付近に分布するサンゴ flst／frstがユニットC-5に対比されるあのであるなら ば，また中部層一上部層間の不整合がこのステージ 16 の最大海水準低下時に形成されたものであるならば， ス テージ 16 の海水準低下の規模の大きさを示すあのであ る。酸素同位体の変動はこのようなステージ 16 におけ る大規模な海水準低下を支持している。島上と海域の坑 井における琉球層群の年代值からみて，ユニットC-5 をステージ 16 に対応させることに問題はない。

\section{6. 結 論}

（1）琉球層群は構成生物の種類と産状により 7 タイプ の石灰岩が識別され，これらの石灰岩は大きくサンゴ石 灭岩相之石灭澡球石灭岩相とに区分される。サンゴ石兏 岩相は島棚内側 礁域の, 石灰藻球石灰岩相は島棚外側 の堆積物に対応する。

（2）琉球層群は層厚 $50 \sim 110 \mathrm{~m}$ ，不整合により下部層・ 中部層・上部層に 3 分され, 下部層はサンゴ石灰岩相, 中部層はサンゴ石灭岩相之石灭澡球石灭岩相の互層, 上 部層は大型有孔虫石灰岩相を主体とする。

（3）中部層は東西方向に岩相が急激に変化し，東部高 地帯ではサンゴ石兏岩相が, 西部低地带では石灰藻球石 灰岩相が主岩相になっている。

(4) 石次質ナンノ化石によると，琉球層群は1.36 $1.10 \mathrm{Ma}$ に堆積を開始し，下部層一中部層間の不整合は $1.10 \sim 0.89 \mathrm{Ma}$ に含まれ，中部層は $0.39 \mathrm{Ma}$ 以前に形成 された。

（5）中部層のサンゴ石死岩相一石灰藻球石灰岩相加ら なる堆積サイクルは氷河性海水準変動に対応して形成さ れ，Williams et al. (1988) の酸素同位体ステージ 26〜16 に対比される可能性が指摘される。高海水準 時には石灭藻球石灭岩相が島の東部へと，低海水準時 にはサンゴ石灰岩相が島の西部へとその分布域を拡大し た。

\section{謝 辞}

本論は1986年以来石油公団石油開発技術センターが大 型研究『眝留岩形成過程解析技術』の中で行ってきた琉 球層群に関する一連の調相・研究の成果を踏まえてまと めたものである。この間調查・研究に携わってきた本研 究センター地質・地化学研究室の方々に深甚なる謝意を 表す。金沢大学理学部小西健二教授, 東北大学理学部中 森亨助教授，井龍康文博士には貴重なご助言をいただい た。日本オイルエンジニアリング株式会社中川 洋氏に は，調査・研究期間を通じて様々なご助言とご協力を睗っ
た。住鉱コンサルタント株式会社佐渡耕一郎氏には伊良 部島の地質に関し，未公表資料を含む種々の情報を教示 していただいた。伊良部町役場の方々には調査に際しご 協力を賜った。坑井の掘削は国際鉱業株式会社, 物理計 测コンサルタント株式会社，応用地質株式会社に依頼し た。合わせて深く感謝する。

\section{文 献}

Bathurst, R. G. C., 1971: Carbonate sediments and their diagenesis. Elsevier, Amsterdam, $658 \mathrm{p}$.

Davies, P. J. and Hopley, D. 1983: Growth fabrics and growth rates of Holocene reefs in the Great Barrier Reef. BMR Jour. Aust. Geol. Geophys., 8, 237-251.

Davies, P. J., Symonds, P. A., Feary, D. A. and Pigram, C. J., 1988: Facies models in exploration - The carbonate platforms of northeast Australia. APEA Jour., 28, 123-143.

Doan, D. B., Paseur, J. E. and Fosberg, F. R., 1960: Militaty geology of the Miyako Archipelago, Ryukyu-Retto. U.S. Army Intell. Div., Off. Eng., with personell of U.S. Geol. Surv., $214 p$.

Embry, A. F. and Klovan, J. E., 1971: A Late Devonian reef tract on northeastern Banks Island, Northwest Territories. Bull. Can. Petrol. Geol., 19, 730-781.

Fairbanks, R. G., 1989: A 17,000-year glacioeustatic sea level record: influence of glacial melting rates on the Younger Dryas event and deep-ocean circulation. Nature, 342, 637-642.

Iryu, Y., 1992: Fossil nonarticulated coralline algae as depth indicators for the Ryukyu Group. Trans, Proc. Paleont. Soc. Japan, N. S., 167, 1165-1179.

Iryu, Y. and Matsuda, S., 1988: Depth distribution, abundance and species assemblage of nonarticulated coralline algae in the Ryukyu Islands, South-western Japan. Proc. 6th Coral Reef Symp., 3, 101-106.

井龍康文・中森 亨・山田 努, 1992: 琉球層群に拈け る層序区分単位. 堆積学研報, 36, 57-66.

井龍康文・鈴木 淳, 1990 : 与那国島の琉球群にみられ る Halimeda 石灰岩の堆積環境. 化石, 49, 13-22.

井龍康文・山田 努, 1991 : 徳之島および沖永良部島の 琉球層群に記録された更新世海面変動一予察一。中川 久夫退官記念事業会編: 中川久夫退官記念論集, 73-83, 中川久夫退官記念事業会.

James, N. P., 1984: Introduction to carbonate facies models. In Walker, R. G., ed.: Facies models, 209-212, Geol. Soc. Canada.

古田土俊夫 - 中川 洋, 1993: 琉球列島宮古島西方海域 
の現世炭酸塩堆積物中の底生有孔虫群集. 石油公団技 術センター研究報告, 24, 93-110。

松田伸也・井龍康文・野原昌人, 1992 : 沖縄島周辺海域 のサンゴモ球㧍よびその地質学的意義. 堆積研報, 37, 109-111.

中森 亨, 1982 : 琉球列島宮古島群島の地質. 東北大地 古研邦報, 84, 23-39.

Nakamori, T., 1986: Community structures of Recent and Pleistocene hermatypic corals in the Ryukyu Islands, Japan. Sci. Rep. Tohoku Univ., 2nd Ser. (Geol.), 56, 71-133.

Nelson, C. S., ed., 1988: Non-tropical shelf carbonates-modern and ancient. Sed. Geol., 60, 367p.

Obata, M. and Tsuji, Y., 1992: Quaternary geohistory inferred by seismic stratigraphy of a carbonate province in an active margin, off Miyako Island, South Ryukyus, Japan. Carbonates and Evaporites, 7, 150-165.

Purser, B. H., ed., 1973: The Persian Gulf, Springer-Varlag, 471p.

Roehl, P. O. and Choquette, P. W., ed., 1985: Carbonate petroleum reservoirs. SpringerVerlag, New York, 622p.

佐渡耕一郎・龟尾浩司 - 小西健二 - 結城智也 - 过 喜弘, 1992: 琉球石灰岩の堆積年代についての新知見一沖縄 県伊良部島のボーリングコア試料の石灰質ナンノ化石 分析より一. 地学雑, 101, 127-132.

佐藤時幸・高山俊昭, 1990 : 石灰質ナンノ化石を使うと 地質時代はどこまで分かるか. 石技誌，55，121-128.

Sato, T. and Takayama, T., 1992: A stratigraphically significant new species of the calcareous nannofossil Reticulofenestra asanoi. In Ishizaki, K. and Saito, T., ed.: Centenary of Japanese micropaleontology, 457-460, Terra Sci. Pub.

Scholle, P. A., Bebout, D. G. and Moore, C. H., ed., 1983: Carbonate depositional environments. Mem. Amer. Assoc. Petrol. Geol., 33., $708 \mathrm{p}$.

Sharma, V., Subhedar, S. S., Oda, M. and Honda
N., 1989: Early Pleistocene planktic foraminifera from the Hijikata Formation, Central Japan, and their paleoclimatic implications. Rev. Esp. Micropaleont., 21, 409-416.

高山俊昭, 1978: 石灰質ナンノプランクトン. 高柳洋吉 編: 微化石研究マニュアル, 51-59, 朝倉書店.

Takayama, T. and Sato, T., 1987: Coccolith biostratigraphy of the North Atlantic Ocean, Deep Sea Drilling Project Leg 94. Init. Rep. DSDP. 94, 651-702.

Tsuji, Y., 1993: Tide influenced high energy environments and rhodolith-associated carbonate deposition on the outer shelf and slope off the Miyako Islands, southern Ryukyu Island Arc, Japan. Mar. Geol., 113, 255-271.

辻 喜弘 - 須内寿男 - 山村恒夫 - 古田土俊夫 - 結城智也 岩本 博, 1989 : 琉球列島宮古島西方海域の現世炭酸 塩堆積物之その堆積環境. 月刊地球, 11, 612-617.

辻 喜弘 - 須内寿男 - 山村恒夫 - 古田土俊夫 - 結城智也 岩本 博, 1993: 琉球列島宮古島西方海域の現世炭酸 塩堆積物とその石油地質学的意義. 石油公団石技セン 夕一研究報告, $24,55-77$.

Tucker, M.E. and Wright, V. P. 1990: Carbonate sedimentology. Blackwell Sci. Publ., 482p.

Ujiie, H. and Oki, K., 1974: Uppermost MioceneLower Pleistocene planktonic foraminifera from the Shimajiri Group of Miyako-jima, Ryukyu Islands. Nat. Sci. Mus. Tokyo, Mem., 7, 31-52.

Williams, D. F., Thunell, R. C., Tappa, E., Rio, D. and Raffi, I., 1988: Chronology of the Pleistocene oxygen isotope record: $0-1.88 \mathrm{~m} . \mathrm{y}$. B. P. Palaeogeogr. Palaeoclimat. Palaeoecol., 64, 221-240.

Wilson, J. L., 1975: Carbonate facies in geologic history. Springer-Verlag, Berlin, 471p.

矢崎清貫, 1978 : 伊良部島地域の地質. 5 万分 1 の図幅 宮古島 (19) 第 2 号, 地質調查所, $23 \mathrm{p}$. 